\title{
NO COMBATE À CORRUPÇÃO EMPRESARIAL, COMO INCENTIVAR NORMATIVAMENTE A IMPLEMENTAÇÃO EFETIVA DO COMPLIANCE?
}

\author{
IN THE COMBAT OF CORPORATE CORRUPTION, HOW THE LAW CAN \\ ENCOURAGE THE COMPLIANCE'S EFFECTIVE IMPLEMENTATION?
}

\section{Matheus Vinícius Aguiar Rodrigues}

Graduando em Direito pela Universidade de Brasilia (UnB), no $10^{\circ}$ semestre. Atualmente membro da Clínica Jurídica Eixos - Judiciário e Cidadania, vinculada à FD/UnB. Pesquisador cadastrado nos grupos de pesquisa: GECEM - Grupo de Estudos Constituição, Empresa e Mercado e Direito e Educação. Estagiário. Endereço para acessar este CV: [http://lattes.cnpq.br/0202392936547091]. ORCID: [https://orcid.org/0000-0001-9203-4192] aguiarmr10@gmail.com

Recebido em: 21.05 .2019 Aprovado em: 05.11.2019

ÁreAS do DIREITO: Administrativo; Comercial/Empresarial

RESUMO: Este artigo parte de duas hipóteses para analisar a estrutura de incentivos na implementação de um compliance efetivo, ambas relacionadas aos parâmetros de responsabilização - imputação, culpabilidade, tipicidade e punibilidade - instituídos na Lei 12.846/2013. Ao descrever as variáveis do problema, as quais incidem em um delineamento legislativo e institucional do fenômeno de combate à corrupção, iremos perquirir, na segunda fase, incentivos normativos à adesão de programas de integridade nas organizações empresariais brasileiras. Ao final, propomos um incentivo normativo que perpassa pela interpretação conforme a Constituição da responsabilidade jurídica das empresas na Lei 12.846/2013, nos autos da AD 5.261, em curso no Supremo Tribunal Federal.

Palavras-Chave: Compliance - Direito Administrativo Sancionador - Responsabilidade objetiva - Incentivos normativos.
ABSTRACT: This article is based on two hypotheses to analyze the structure of incentives in the implementation of compliance, both related to the parameters of liability established in Statute 12.846/2013. In describing the variables of the problem, which focus on a legislative and institutional delineation of the anti-corruption phenomenon, in the second phase we will look for legal incentives for adherence to integrity programs in brazilian business organizations. In the end, we propose a legal incentive that perpasses by the "interpretation according to the Brazilian constitution" of the companies' legal in the Statute $12.846 / 2013$, according to DAU (direct action of unconstitutionality, ADI in Portuguese) case 5.261 , in progress in the Federal Supreme Court.

KEYwORDS: Compliance - Administrative Law Sanctioning - Objective Responsibility - Legal incentives.

Rodrigues, Matheus Vinícius Aguiar. No combate à corrupção empresarial, como incentivar normativamente a implementação efetiva do compliance?

Revista de Direito Administrativo, Infraestrutura, Regulação e Compliance n. 13. ano 4. p. 221-249. São Paulo: Ed. RT, abr.-jun. 2020. 
SumÁRIO: 1. Introdução. 2. Descrição do problema. 2.1. Combate à corrupção: a pressão internacional como vetor de mudanças legislativas e institucionais no Brasil. 2.2. Mudanças legislativas e institucionais no cenário brasileiro. 2.3. Compliance anticorrupção: a nossa definição. 2.4. A Lei Anticorrupção: aspectos gerais e o papel conferido ao compliance no Decreto 8.420/2015. 3. Descrição da solução. 3.1. Fundamento adequado para a responsabilidade jurídica das empresas na LAC: interpretação conforme à Constituição Federal de 1988 na ADI 5.261. 4. Conclusão. Referências.

\section{InTRODUÇão}

O objetivo desse artigo é perquirir o combate à corrupção empresarial a partir da análise de uma ferramenta, o compliance. Partimos de duas hipóteses: que 1) a Lei Anticorrupção (LAC) pode ser fonte de punições arbitrárias e desarrazoáveis, sobretudo pela junção do instituto da 1.1) responsabilidade objetiva, de 1.2) ilícitos de tipicidade aberta e de perigo abstrato e, ainda, pela 1.3) competência que ela confere a diversos órgãos para aplicá-la, na persecução da responsabilidade administrativa e civil, dando ensejo a uma maior possibilidade de interpretações contraditórias na aplicação desse estatuto normativo; que 2) a LAC não adota um parâmetro de imputação e culpabilidade, na responsabilização da pessoa jurídica, que incentive, da forma mais efetiva possível, a autorregulação empresarial.

A análise dessas hipóteses e da estrutura de incentivos normativos à adoção de programas de integridade exige, não obstante, incursões prévias. Dessa maneira, na primeira fase, encontra-se a descrição do problema que deu ensejo a esse artigo. Nos primeiros capítulos, o leitor será ambientado ao contexto internacional que entronizou pressão para a edição da Lei Anticorrupção (LAC) e ambientado ao atual cenário de combate à corrupção no Brasil. Em seguida, define-se a ferramenta a partir da qual buscamos estudar o combate à corrupção empresarial, o compliance, apresentando o papel deste na responsabilização da pessoa jurídica pela prática de um ilícito. A partir da descrição desse fenômeno, no fim da primeira fase, o leitor será introduzido ao nosso problema: como gerar incentivos normativos à adoção do compliance pelas sociedades empresariais?

Na segunda fase, nossa proposição é apresentada. Ela parte do pressuposto teórico que julgamos responder adequadamente às nossas hipóteses: (i) o fundamento constitucionalmente adequado à responsabilização das pessoas jurídicas e, ainda, o (ii) papel que apontamos como adequado aos programas de integridade nessa responsabilização.

Dessa forma, ao fim, propomos um incentivo normativo para que a ferramenta analisada possa ser mais efetiva no combate à corrupção empresarial, buscando estimular empregador e empregado na promoção de uma cultura ética

Rodrigues, Matheus Vinicius Aguiar. No combate à corrupção empresarial, como incentivar normativamente a implementação efetiva do compliance? 
empresarial, o qual é baseada: (a) em uma interpretação conforme a Constituição Federal/1988 da responsabilidade das pessoas jurídicas instituídas pela LAC, mormente a partir da ADI 5.261, em curso no Supremo Tribunal Federal (STF).

\section{DESCRIÇÃO DO PROBLEMA}

\subsection{Combate à corrupção: a pressão internacional como vetor de mudanças legislativas e institucionais no Brasil}

Ao longo desta obra restará latente a importância do cenário internacional como vetor das iniciativas nacionais sobre o tema. Desde logo, cabe destacar que a pressão internacional pela uniformização mundial sobre legislações anticorrupções reflete dois interesses. O primeiro é relativo à concorrência, já que haveria uma igualdade competitiva à medida que empresas estivessem sujeitas a normas e a custos decorrentes destas semelhantes ${ }^{1}$. O segundo se refere à necessidade de combate a um fenômeno transnacional.

Dessa maneira, sobretudo a partir da década de 1990, percebe-se o recrudescimento de uma cooperação internacional no combate à corrupção e à prática de subornos e propinas a agentes estrangeiros ${ }^{2}$. Essa pressão internacional pela uniformização sobre o tema culmina na Convenção das Nações Unidas contra a Corrupção ${ }^{3}$ (2003), momento no qual o movimento de combate à corrupção se consolida em nível internacional. Nessa Convenção, destaca-se o compromisso dos 178 Estados signatários para a edição de legislações que estabelecessem a responsabilidade - civil, administrativa ou penal - das pessoas jurídicas por participação nos ilícitos ali dispostos ${ }^{4}$.

1. Nesse sentido, destaca-se: "Legislações anticorrupção frequentemente impõem custos, requisitos e exigências a empresas e indivíduos. Nesse cenário, é importante para a sua competitividade que empresas e indivíduos estrangeiros também estejam sujeitos a essas normas" (MOHALLEM, Michael Freitas; RAGAZZO, Carlos Emmannue Joppert. Diagnóstico Institucional: primeiros passos para um plano nacional anticorrupção. Rio de Janeiro: Escola de Direito do Rio de Janeiro da Fundação Getulio Vargas, 2017. p. 39).

2. Houve, nesse período, a assinatura de diversos acordos internacionais, como a Convenção Interamericana contra a Corrupção (1996) e a Convenção sobre o Combate à Corrupção de Funcionários Públicos Estrangeiros em Transações Internacionais - da OCDE (Organização para a Cooperação e Desenvolvimento Econômico), em 1997.

3. Essa Convenção foi ratificada e incorporada ao ordenamento jurídico brasileiro pelo Decreto Presidencial 5.687/2006.

4. Previsão contida no artigo 26 da Convenção das Nações Unidas Contra a Corrupção.

RooRIGues, Matheus Vinicius Aguiar. No combate à corrupção empresarial, como incentivar normativamente a implementação efetiva do compliance?

Revista de Direito Administrativo, Infraestrutura, Regulação e Compliance n. 13. ano 4. p. 221-249. São Paulo: Ed. RT, abr.-jun. 2020. 
Ressaltam-se, como indício do recrudescimento desse movimento internacional, a intensificação no combate à corrupção, nos EUA, com a aumento das sanções aplicadas com base no Foreign Corrupt Pratices Act (FCPA) ${ }^{5}$ e, ainda, a edição do UK Bribery Act (2010), no Reino Unido. Em síntese, esse movimento internacional de combate à corrupção exigiu diversas mudanças estruturais e legislativas, por parte dos Estados, que deu ensejo, posteriormente, à criação de uma rede de incentivos (jurídicos e metajurídicos) para que as empresas ${ }^{6}$ pudessem adotar programas internos de integridade, que é a ferramenta que analisaremos nesse jogo.

\subsection{Mudanças legislativas e institucionais no cenário brasileiro}

No Brasil, o recrudescimento do combate à corrupção, que, como vimos, deu estímulos à autorregulação privada, reflete e decorre dessa pressão internacional. Em 1997, após participar do Comitê da Basiléia e pactuar, junto às demais integrantes, o Core Principles for Effective Banking Supervision, o Brasil editou a Lei de Combate à Lavagem de Dinheiro (Lei 9.613/1998), que estipula obrigações a serem seguidas pelas "pessoas sujeitas ao mecanismo de controle", vinculando-se essas ao dever de reportar operações atípicas e suspeitas.

Dessa maneira, a partir do advento destes dispositivos normativos (a Lei Federal 9.613/19987 e os princípios estipulados no Comitê da Basileia), o Banco Central do Brasil (BACEN) editou, posteriormente, a Resolução 2.554/1998, que determina às instituições financeiras a criação e a implementação de programas de integridade e a observância às leis aplicáveis ao setor ${ }^{8}$.

5. MENDES, Franciso Schertel; DE CARVALHO, Vinícius Marques. Compliance: concorrência e combate à corrupção. São Paulo: Trevisan Editora, 2017. p. 13-14.

6. Nesse sentido, destaca-se: “A autorregulação é essencial, portanto, para a construção de uma cultura de respeito à legalidade e à ética, uma vez que os incentivos para o cumprimento da lei passam a ser internos e desenvolvidos pela sociedade em lugar de serem externos e impostos pelo Estado" (FRAZÃO, Ana. Programas de compliance e critérios de responsabilização de pessoas jurídicas por ilícitos administrativos. In: ROSSETII, Maristela Abla; PITTA, Andre Grunspun (Coord.). Governança corporativa: avanços e retrocessos. São Paulo: Quartier Latin, 2017. p. 19).

7. Posteriormente, com a edição da Lei 12.683/2012, que reformou a Lei de Combate à Lavagem de Dinheiro, editou-se expressamente disposição legal sobre os programas de integridade, antes só disposto na Resolução do BACEN. Essa previsão está contida no art. 10 da referida lei.

8. Previsão contida no art. $1^{\circ}$ da Resolução 2.554/1998, do Banco Central do Brasil.

Rodrigues, Matheus Vinícius Aguiar. No combate à corrupção empresarial, como incentivar normativamente a implementação efetiva do compliance?

Revista de Direito Administrativo, Infraestrutura, Regulação e Compliance.

n. 13. ano 4. p. 221-249. São Paulo: Ed. RT, abr.-jun. 2020. 
Dessa maneira, o conceito e a própria noção da autorregulação, por meio de programas de integridade, não se originam na Lei Anticorrupção, embora seja com essa que ganham notoriedade. Essa previsão instituída na Resolução do BACEN, paulatinamente, espraia-se para outros setores e empresas, mormente a partir do recrudescimento de mecanismos de detecção da corrupção e dos incentivos positivados, posteriormente, na LAC.

Dessa forma, esse movimento que confere importância a esse instituto se insere em um fenômeno que perpassa por três momentos e que se confunde, invariavelmente, com o combate à corrupção (prevenção, detecção e punição).

O primeiro deles é o monitoramento da corrupção ${ }^{9}$ e a publicidade de índices criados para tal. Nesse sentido, destacam-se: o Corruption Perception Index (1995), da Transparência Internacional, que avalia o grau de 176 países em que a corrupção pode ser percebida entre os funcionários públicos ${ }^{10}$; o relatório do Fórum Econômico Mundial, The Global Competitiveness Report (2016-2017) ${ }^{11}$, que integra aspectos macroeconômicos e microeconômicos relacionados à competitividade, entre os quais se avaliam a ética e a corrupção; e, ainda, os índices

9. Mais recentemente, em obra exaustiva sobre o tema, destaca-se o diagnóstico institucional realizado pela FGV RIO (MOHALLEM, Michael Freitas; RAGAZZO, Carlos Emmannue Joppert. Op. cit., p. 159).

10. No relatório da Organização, em 2017, o Brasil esteve na $79^{a}$ posição, entre os 176 países avaliados, no que tange à percepção da corrupção (disponível em: [https:// www.transparency.org/news/feature/corruption_perceptions_index_2017]. Acesso em: 02.06.2018).

11. The Global Competitiveness Report 2016-2017 aponta índices alarmantes relacionados ao impacto da corrupção na competitividade e no desenvolvimento empresarial no Brasil. Em pesquisa de opinião, a corrupção é apontada como o segundo fator mais problemático nos negócios, no Brasil, perdendo apenas para o valor dos impostos. Destacam-se, também, indices do 1st Pillar: Institutions, analisado pelo Relatório, e, especificamente, os índices 1.04 (Public trust in politicians, que coloca o Brasil em último lugar no rank); o 1.05 (Irregular payments and bribes, que coloca o Brasil na $11^{\mathrm{a}}$ posição); o 1.12 (Transparency of government policymaking, que coloca o Brasil na $130^{\mathrm{a}}$ posição, de 138 países analisados); e o 1.17 (Ethical behavior of firms, que coloca o Brasil na $131^{a}$ posição). Esse primeiro pilar, relacionado às Instituições, é o que mais impacta negativamente a competitividade empresarial e econômica do Brasil (WORLD ECONOMIC FORUM. The Global Competitiveness Report 2017-2018. Disponivel em: [www3.weforum.org/docs/GCR2016-2017/05FullReport/TheGlobalCompetitivenessReport2016-2017_FINAL.pdf]. Acesso em: 02.06.2018).

RodRIgues, Matheus Vinicius Aguiar. No combate à corrupção empresarial, como incentivar normativamente a implementação efetiva do compliance?

Revista de Direito Administrativo, Infruestrutura, Regulação e Compliance. n. 13. ano 4. p. 221-249. São Paulo: Ed. RT, abr.-jun. 2020. 
que calculam o prejuízo econômico ao PIB $^{12}$ (Produto Interno Bruto) decorrente da corrupção $0^{13-14}$.

Desse monitoramento advém a pressão pública (nacional e internacional) que, como já foi ressaltado, é vetor na criação de políticas públicas e no aprimoramento legislativo sobre o tema. Esses mecanismos buscarão uma maior eficácia na prevenção, detecção e punição à prática de atos ilícitos.

Isso nos conduz ao segundo momento, no qual se destaco a produção legislativa sobre o tema ${ }^{15}$. Dentro da legislação atual, o foco deste trabalho se circunscreve à Lei Anticorrupção e aos instrumentos normativos que dela advêm, como o Decreto 8.240/2015 e, ainda, as Leis Estaduais que dispõem sobre a obrigatoriedade do compliance para contratar com a Administração Estadual ${ }^{16}$.

12. Em relatório da Fiesp (Federação das Indústrias do Estado de São Paulo), em 2010, por exemplo, apontou-se que a corrupção traz um prejuízo equivalente a 2,3\% do PIB brasileiro, estimado em $\mathrm{R} \$ 69,1$ bilhões. Segundo os cálculos, isso poderia representar um incremento de $27 \%$ do produto per capita brasileiro (DECOMTEC/FIESP. Relatório Corrupção: custos econômicos e propostas de combate. 2010. Disponível em: [www.fiesp. com.br/arquivo-download/?id=2021]. Acesso em: 02.06.2018).

13. Nesse sentido, destaco as conclusões contidas na obra de Eduardo Gianetti, que aponta o impacto da "qualidade dos jogadores" (agentes econômicos) e do "árbitro da partida" (agente público) no PIB, ressaltando que a corrupção está associada à deturpação de elementos fundamentais na concorrência econômica, como a inovação, a eficiência, a produtividade e o crescimento. Ademais, friso, ainda, a leitura e a bibliografia apresentada pelo autor para indicar os impactos extraeconômicos da corrupção, como no capital humano qualificado, que é apresentado como "a essência do desenvolvimento" (GIANNETI, Eduardo. Vícios privados, benefícios públicos? A ética na riqueza das nações. São Paulo: Companhia de Bolso, 2007. p. 159;197).

14. Para saber mais sobre os impactos da corrupção, destaca-se a obra de Marco Aurélio Borges de Paula, que abarca bibliografia essencial sobre o tema, abordando os tipos de corrupção (petty corruption e grand corruption), bem como os impactos econômicos, sociais e políticos dela no desenvolvimento de uma nação (PAULA, Marco Aurélio Borges de. Efeitos da corrupção para o desenvolvimento. In: PAULA, Marco Aurélio Borges de; CASTRO, Rodrigo Pironti Aguirre de (Coord.). Compliance, gestão de riscos e combate à corrupção: integridade para o desenvolvimento. Belo Horizonte: Fórum, 2018. p. 21-44).

15. Cronologicamente, destacam-se: a Lei Sobre Crimes Financeiros (Lei 7.492/1986); a Lei de Inelegibilidade (Lei Complementar 64/1990); a Lei de Improbidade Administrativa (Lei 8.429/1992); a Lei de Licitações (Lei 8.666/1993); a Lei da Lavagem de Dinheiro e Criação do Conselho de Controle de Atividades Financeiras (Lei 9.613/1998); a Lei de Responsabilidade Fiscal (Lei Complementar 101/2000); a Lei da Ficha Limpa (Lei Complementar 135); a Lei de acesso à informação (Lei 12.527/2011); e, recentemente, a Lei Anticorrupção (Lei 12.846), foco desta análise.

16. Nesse sentido, até o momento, destacam-se a Lei Estadual 7.753/2017, do Rio de Janeiro, e a Lei 6.612/2018, do Distrito Federal. 
No terceiro e último momento desse fenômeno que me proponho a apresentar, não se pode olvidar de reconhecer a intensificação da atividade institucional dos órgãos que atuam constitucionalmente na prevenção e detecção da corrupção, no Brasil. Nesse sentido, a Constituição Federal/1988 estabelece uma estrutura institucional na qual o Ministério Público e os Tribunais de Contas possuem papel importante na fiscalização e no combate a ilícitos contra o erário.

Ademais, diversos outros órgãos se inserem nesse fenômeno, como a CGU (Controladoria-Geral da União ${ }^{17}$ ), com competência, instituída pela Lei 10.683/ 2003, que, em síntese, visa a defesa do patrimônio público no Poder Executivo Federal. Cita-se, também, a Polícia Federal, que tem se destacado pelas operações deflagradas na investigação e no combate aos ilícitos contra a Administração Pública Federal.

Isto posto, após apresentar esse fenômeno institucional e legislativo que confere à autorregulação uma ferramenta importante no combate à corrupção, cabe apresentar como esta obra define o compliance. E isso será feito em uma rápida digressão ao próximo capítulo. Posteriormente, será analisado o papel conferido ao compliance nesse jogo, como última incursão necessária à introdução do nosso problema.

\subsection{Compliance anticorrupção: a nossa definição}

Compliance se trata de um termo anglo-saxão originado do verbo inglês comply with (cumprir com) e se refere a um conjunto de mecanismos de autovigilância e de promoção de uma cultura empresarial ética, que conduz à observância das legislações aplicáveis ${ }^{18-19-20}$. Dessa maneira, de forma ampla, compliance

17. Renomeada pelo Decreto 8.109/2013 como Secretaria de Transparência e Prevenção da Corrupção. Posteriormente, com a Lei 13.266/2016, renomeada como Ministério da Fiscalização, Controle e Transparência. As disposições legais aplicáveis ao órgão continuam as mesmas.

18. Em 1991, as U.S. Sentencing Commission's Organizational Guidelines, ao buscar evitar disparidades nas sentenças americanas, já previam, como atenuante, a existência de um "compliance and ethics program".

19. Nesse sentido, destaca-se a definição da professora e advogada Ana Frazão na qual afirma que "(...) compliance diz respeito ao conjunto de ações a serem adotadas no ambiente corporativo para que se reforce a anuência da empresa à legislação vigente, de modo a prevenir a ocorrência de infrações ou, já tendo ocorrido o ilícito, propiciar o imediato retorno ao contexto de normalidade e legalidade." (FRAZÃO, Ana. Op. cit., p. 18).

20. O Decreto $8.420 / 2015$, em seu artigo 41 , define programas de integridade como “(...) conjunto de mecanismose procedimentos internos de integridade, auditoria eincentivo

Roorigues, Matheus Vinicius Aguiar. No combate à corrupção empresarial, como incentivar normativamente a implementação efetiva do compliance?

Revista de Direito Administrativo, Infraestrutura, Regulação e Compliance n. 13. ano 4. p. 221-249. São Paulo: Ed. RT, abr.-jun. 2020. 
não se refere apenas ao cumprimento das leis, mas sim à criação de uma cultura empresarial que estimule essa observância ${ }^{21}$. Não obstante, este trabalho se restringirá a uma concepção restrita do termo (compliance anticorrupção), que se delimita à observância exclusiva da legislação de combate à corrupção no desenvolvimento regular das atividades da empresa ${ }^{22}$.

Nesse sentido, o compliance anticorrupção será responsável por quebrar o Triângulo de Fraude ${ }^{23} \mathrm{em}$ uma corporação empresarial, na qual se busca evitar a prática do ilícito a partir de um combate em três frentes: removendo l) a pressão (seja interna, como a pressão por resultados, seja externa/motivação pessoal) para se cometer um ilícito; removendo 2) a racionalização (pessoal ou mercadológica) que justifique a prática de um ilícito e, ainda, 3) removendo as oportunidades a partir das quais se possa cometer um ilícito (sendo este gerenciamento de riscos um dos papéis mais importantes do compliance).

à denúncia de irregularidades e na aplicaçăo efetiva de códigos de ética e de conduta, políticas e diretrizes com objetivo de detectar e sanar desvios, fraudes, irregularidadese atos ilícitos praticados contra a administração pública, nacional ou estrangeira" (BRASIL. Decreto 8.420, de 18 de março de 2015. Regulamenta a Lei 12.846 , de $1^{\circ}$ de agosto de 2013, que dispõe sobre a responsabilização administrativa de pessoas jurídicas pela prática de atos contra a administração pública, nacional ou estrangeira e dá outras providências. Disponível em: [www.planalto.gov.br/CCIVil_03/_Ato2015-2018/2015/Decreto/D8420.htm]. Acesso em: 02.06.2018).

21. Destaca-se, dessa maneira, o apontamento de Alexandre da Cunha Serpa no qual afirma que "programas de compliance não são sobre as leis, mas sim sobre querer seguir as leis" (SERPA, Alexandre da Cunha. Guia descomplicado: um guia simples e direto sobre Programas de Compliance. 2016. p. 12, grifo nosso).

22. Nesse sentido: "Vê-se, assim, certa ambivalência de sua acepção: em termos amplos, refere-se à observância de parâmetros não só legais, mas também de caráter ético e de política empresarial, enquanto em sentido estrito faria referência exclusiva à normativa legal pertinente" (SILVEIRA, Renato de Mello Jorge; SAAD-DINIZ, Eduardo. Compliance, direito penal e lei anticorrupção. São Paulo: Saraiva, 2015. p. 65). Destaca-se, ainda, que compliance abrange diversos tópicos jurídicos e metajurídicos não abarcados nessa concepção restrita adotada neste trabalho, como regras de saúde e segurança, ambiente de trabalho, relacionamento com as empresas que fazem parte da cadeia de negócios da empresa, gestão de terceiros, práticas concorrenciais (fair competition), doações e patrocínios, viagens, presentes, assédio, discriminação, controles financeiros, registros contábeis, canais de denúncias, conflitos de interesse e diversos outros tópicos que não, necessariamente, refletem-se, direta ou indiretamente, na legislação de combate à corrupção (Lei 12.846/2013).

23. SCHUESSLER, Karl F. Other People's Money: A Study in the Social Psychology of Embezzlement. Donald R. Cressey. American Journal of Sociology 59, Chicago, 6, p. 604, maio 1954. Disponível em: [https://doi.org/10.1086/221475]. Acesso em: 27.06.2018.

Rodrigues, Matheus Vinicius Aguiar. No combate à corrupção empresarial, como incentivar normativamente a implementação efetiva do compliance? 
Nesta obra, define-se compliance como uma "ferramenta meio não suficiente" instituída pelo legislador no combate à corrupção, nos níveis da prevenção e detecção desta. Explica-se: o compliance, por si só, não combate a corrupção. Ele é apenas mais um dos incentivos que, aliados a outros, como sanções (incentivos negativos) e como políticas públicas, atuarão no combate a esse fenômeno. Além disso, o compliance é meio, e não um fim em si mesmo: o compliance é uma forma pela qual se intenta a criação de uma cultura empresarial ética; uma ponte, um vetor de incentivo.

Isto posto, introduz-se a última incursão necessária à apresentação do nosso problema, que apresentará o papel que o legislador confere aos programas de integridade, apresentando-se, para tal, a Lei Anticorrupção (LAC), o decreto que a regulamenta e, a partir disso, os custos de transação na implementação de um compliance efetivo.

\subsection{A Lei Anticorrupção: aspectos gerais e o papel conferido ao compliance no Decreto 8.420/2015}

A Lei Anticorrupção (LAC) advém de Projeto de Lei (PL) apresentado pelo Presidente da República à Câmara dos Deputados, o PL 6.826-A/2010. Houve 49 emendas parlamentares e intensas discussões dentro desse anteprojeto, o qual buscou solucionar uma lacuna legislativa e suprir um compromisso internacional do Brasil: editar uma previsão legal que almejasse, de forma efetiva, a responsabilização das empresas por ilícitos praticados contra a Administração Pública, nacional ou estrangeira ${ }^{24}$.

Desde logo, cabe destacar que, no anteprojeto, já havia a previsão dos programas de integridade como atenuante das sanções aplicadas. Não obstante, um dos cernes das discussões parlamentares girava em torno da suposta responsabilidade objetiva das empresas. Justificável. Como será ressaltado na segunda fase, discutir sobre incentivos normativos à implementação do compliance perpassa inevitavelmente pela análise dos fundamentos da responsabilização das pessoas jurídicas e pelo papel conferido aos programas de integridade na LAC.

24. O PL 6.286-A/2010 apresentava, nas suas justificativas, o "objetivo de suprir uma lacuna existente no sistema jurídico pátrio no que tange à responsabilização de pessoas jurídicas pela prática de ilícitos contra a Administração Pública, em especial, por atos de corrupção e fraude em licitações e contratos administrativos". Ressalta-se, também, que o projeto representou um compromisso pactuado pelo Brasil na Convenção das Nações Unidas contra a Corrupção, em 2003, como já ressaltado anteriormente neste trabalho. Mais uma vez, reafirma-se a importância desse cenário internacional nas iniciativas nacionais sobre o tema.

Rodrigues, Matheus Vinícius Aguiar. No combate à corrupção empresarial, como incentivar normativamente a implementação efetiva do compliance?

Revista de Direito Administrativo, Infraestrutura, Regulação e Compliance.

n. 13. ano 4. p. 221-249. São Paulo: Ed. RT, abr.-jun. 2020. 
Entre as justificativas, o autor do PL 6.826-A/2010 destacou a "disposição salutar e inovadora" da responsabilização objetiva das pessoas jurídicas ${ }^{25}$ e, ainda, a vontade do proponente do anteprojeto de afastar a responsabilização penal dessas empresas, sobretudo pela ausência de "mecanismos efetivos ou céleres para punir as sociedades empresárias"26.

Entre as emendas parlamentares, no processo legislativo, cerca de 8 (oito) de$\operatorname{las}^{27}$ buscavam discutir o alcance e a constitucionalidade da responsabilização

25. Nesse sentido: "Disposição salutar e inovadora é a da responsabilização objetiva da pessoa jurídica. Isso afasta a discussão sobre a culpa do agente na prática da infração. A pessoa jurídica será responsabilizada uma vez comprovados ofato, o resultado e o nexo causal entre eles. Evita-se, assim, a dificuldade probatória de elementos subjetivos, como a vontade de causar um dano, muito comum na sistemática geral e subjetiva de responsabilização de pessoas naturais" (BRASIL. Congresso Nacional. Projeto de Lei 6.826-A, do Poder Executivo, de 18 de fevereiro de 2010 , que dispõe sobre a responsabilização administrativa e civil de pessoas jurídicas pela prática de atos contra a administração pública, nacional e estrangeira e dá outras providências; p. 9, grifo meu. Disponível em: [www.camara. gov.br/proposicoesWeb/prop_mostrarintegra? codteor=1084183\&filename=Avulso+-PL+6826/2010]. Acesso em: 10.01.2018).

26. Nesse sentido: "Observe-se que o presente projeto optou pela responsabilização administrativa e civil da pessoa juridica, porque o Direito Penal não oferece mecanismos efetivos ou céleres para punir as sociedades empresárias, muitas vezes as reais interessadas ou beneficiadas pelos atos de corrupção. A responsabilização civil, porque é a que melhor se coaduna com os objetivos sancionatórios aplicáveis às pessoas jurídicas, como por exemplo o ressarcimento dos prejuízos econômicos causados ao erário; e o processo administrativo, porque tem-se revelado mais célere e efetivo na repressão de desvios em contratos administrativos e procedimentos licitatórios, demonstrando melhor capacidade de proporcionar respostas rápidas à sociedade" (grifo nosso) (BRASIL. Congresso Nacional. Projeto de Lei 6.826-A, do Poder Executivo, de 18 de fevereiro de 2010, que dispõe sobre a responsabilização administrativa e civil de pessoas jurídicas pela prática de atos contra a administração pública, nacional e estrangeira e dá outras providências; p. 10, grifo meu. Disponível em: [www.camara.gov.br/proposicoesWeb/ prop_mostrarintegra? codteor $=1084183 \&$ filename $=$ Avulso $+-P L+6826 / 2010]$. Acesso em: 10.01.2018).

27. As Emendas 8/2011 e 12/2011, de autoria do Deputado Edio Lopes (PMDB/RR); a Emenda 11/2011, de autoria do Deputado João Magalhães (PMDB/MG); a Emenda 17/2011, de autoria do Deputado Natan Donadon; a Emenda 26/2011, de autoria do Deputado Duarte Nogueira (PSDB/SP); após discussões e audiências públicas, houve, ainda, as Emendas ao $1^{\circ}$ Substitutivo ao Projeto de Lei 6.826/2010, entre as quais: as Emendas ao Substitutivo 11/2012, 12/2012 e 13/2011, de autoria do Deputado Laercio Oliveira, que visavam excluir a responsabilidade objetiva (por considerá-la inconstitucional) e, além disso, fazer com que o compliance não apenas atenuasse a pena, mas também rompesse o nexo causal da responsabilidade da empresa (BRASIL. Congresso Nacional. Projeto de Lei 6.826-A, do Poder Executivo, de 18 de fevereiro de 2010, que dispõe

Rodrigues, Matheus Vinicius Aguiar. No combate à corrupção empresarial, como incentivar normativamente a implementação efetiva do compliance?

Revista de Direito Administrativo, Infroestrutura, Regulaçấo e Compliance.

n. 13. ano 4. p. 221-249. São Paulo: Ed. RT, abr.-jun. 2020. 
objetiva das empresas. Depois de audiências públicas, discussões legislativas e, sobretudo, após parecer da então CGU (Controladoria-Geral da União) acerca da constitucionalidade e da necessidade da manutenção do texto legal do anteprojeto ${ }^{28}$, a responsabilidade objetiva foi aprovada no Congresso Nacional e sancionada pelo Presidente da República, na chamada Lei Anticorrupção, a Lei 12.846/2013.

Ela prevê a responsabilização objetiva - administrativa e civil - às pessoas jurídicas pelas práticas de atos ilícitos, didaticamente, resumidos nos 1) atos lesivos ligados ao oferecimento de vantagens indevidas; nos 2) atos lesivos realizados no âmbito de licitações e contratos administrativos; e, por fim, nos 3) atos lesivos praticados para dificultar ou impedir a atividade de fiscalização do Estado ${ }^{29}$.

Trata-se de ilícitos com tipos nucleares extremamente abrangentes e genéricos, numa tipificação aberta ${ }^{30}$. Dessa maneira, o legislador se vale de verbos nucleares amplos e de difícil definição, como "fraudar", "criar", "prometer", "perturbar", sobretudo pela natural dificuldade em se tipificar todos os atos de corrupção possíveis e imagináveis que possam ser praticados. Ademais, os ilícitos

sobre a responsabilização administrativa e civil de pessoas jurídicas pela prática de atos contra a administração pública, nacional e estrangeira e dá outras providências; p. 28-29. Disponível em: [www.camara.gov.br/proposicoesWeb/prop_mostrarintegra? codteor $=1084183 \&$ filename $=$ Avulso+-PL+6826/2010]. Acesso em: 10.01.2018).

28. BRASIL. Congresso Nacional. Projeto de Lei 6.826-A, do Poder Executivo, de 18 de fevereiro de 2010, que dispõe sobre a responsabilização administrativa e civil de pessoas jurídicas pela prática de atos contra a administração pública, nacional e estrangeira e dá outras providências; p. 110-111. Disponível em: [www.camara.gov.br/proposicoesWeb/prop_mostrarintegra? codteor=1084183\&filename=Avulso+-PL+6826/2010] . Acesso em: 10.01.2018.

29. As condutas ilícitas estão dispostas no art. $5^{\circ}$ da Lei 12.846/2013.

30. Acerca da tipificação aberta no Direito Administrativo Sancionador, OSÓRIO, Fábio Medina. Direito administrativo sancionador. 2. ed. São Paulo: Ed. RT, 2006. p. 269. Essas lições são rememoradas e aprofundadas, na análise do Direito Administrativo Sancionador, da qual se valeu o Ministro Relator Celso de Melo, nos autos do MS 28.799/DF, no STF, DJe de 06.10.2016, no qual se destaca a seguinte passagem: "O reconhecimento da possibilidade de instituição de estruturas típicas flexíveis no âmbito do direito administrativo sancionador, cuja textura aberta conduz à necessidade de o órgão disciplinar -com apoio em seu prudente critério e sempre atento às limitações que derivam dos princípios da proporcionalidade e da razoabilidade - proceder à adequada correlação entre a infração funcional e a sanção a ela correspondente prevista no estatu to jurídico-disciplinar, tem o beneplácito de autorizado magistério doutrinário (...)".

RODRIGUE5, Matheus Vinícius Aguiar. No combate à corrupção empresarial, como incentivar normativamente a implementação efetiva do compliance? Revista de Direito Administrativo, Infraestrutura, Regulação e Compliance. n. 13. ano 4. p. 221-249. São Paulo: Ed. RT, abr.-jun. 2020 
puníveis na Lei Anticorrupção são classificados como infrações de perigo ${ }^{31-32}$, isto é, a configuração do ilícito independe de dano ao erário.

A responsabilização administrativa, prevista na Lei Anticorrupção, é disciplinada pelo Decreto 8.420/2015 e se processa mediante a instauração de um Processo Administrativo de Responsabilização (PAR) pela autoridade máxima da entidade em face da qual o ato ilícito fora praticado ${ }^{33}$, que também se responsabiliza pelo julgamento ${ }^{34}$.

Percebe-se, então, que a Lei Anticorrupção optou por não concentrar em um órgão a aplicação dessa legislação ${ }^{35}$, na esfera administrativa. Inegavelmente, essa máxima horizontalidade, na persecução da configuração da reponsabilidade administrativa, aumenta a probabilidade da aplicação não uniforme da lei, sobretudo em virtude da presença de vários intérpretes que aplicam a LAC.

Ao fim do trâmite do PAR, às empresas pode ser aplicada uma decisão administrativa sancionadora, com a aplicação das sanções previstas no art. $6^{\circ}$ da Lei $12.846 / 2013$, as quais seriam a 1) multa e/ou a 2) publicação extraordinária da decisão condenatória. A partir da edição do Decreto 8.420/2015, ainda, foi

31. Nesse sentido, destaca-se: "A conduta pode se resumir ao simples atentado sem resultar em prejuizo efetivo, embora pareça insuficiente a mera intenção de ofensa, pois atentado, aqui, significa mais do que apenas a cogitação exigindo-se ameaça real e concreta de lesão não exaurida, ainda que interrompida a execução por desistência ou causa alheia à vontade" (DIPP, Gilson; CASTILHO, Manoel L. Volkmer de. Comentârios sobre a Lei anticorrupção. São Paulo: Saraiva, 2016. p. 39, grifo meu).

32. Ainda nesse contexto: "Entendemos que para a aplicação da Lei Anticorrupção não será necessária a efetiva ocorrência do dano, entretanto, o aplicador da sanção deve analisar cada caso concreto, principalmente em se tratando de responsabilização objetiva, para interpretar a lei de forma proporcional e razoável" (MARINELA, Fernanda; RAMALHO, Tatiany; PAIVA, Fernanda. Lei anticorrupção: Lei n. 12.846 , de $1^{\circ}$ de Agosto de 2013. São Paulo: Saraiva, 2015. p. 85).

33. Em caso de órgão da Administração direta, a instauração e julgamento do PAR (Processo Administrativo de Responsabilização) será do Ministro de Estado, nos termos do art. $3^{\circ}$ do Decreto 8.420/2015.

34. Nesse sentido, destaca-se o Capítulo I do Decreto 8.420/2015, que disciplina a responsabilização administrativa.

35. No Direito Comparado, por exemplo, há exemplos que caminham no sentido inverso, como o Reino Unido. Neste há uma centralidade na Serious Fraud Office (SFO), responsável por investigar, tendo farta iniciativa instrutória, e realizar a persecução criminal em casos complexos de corrupção, suborno e fraudes. O Bribery Act britânico introduziu a responsabilidade criminal das empresas por um tipo penal omissivo ("fracasso em prevenir a corrupção"), destacando, nesse ponto, o papel que um compliance efetivo possui em afastar o nexo causal da responsabilidade da pessoa jurídica.

RodRIgues, Matheus Vinicius Aguiar. No combate à corrupção empresarial, como incentivar normativamente a implementação efetiva do compliance?

Revista de Direito Administrativo, Infraestrutura, Regulação e Compliance,

n. 13. ano 4. p. 221-249. São Paulo: Ed. RT, abr.-jun. 2020. 
regulamentado o Cadastro Nacional de Empresas Inidôneas e Suspensas (CEIS) e o Cadastro Nacional de Empresas Punidas (CNEP), os quais passaram a ser integrados por essas empresas penalizadas e, portanto, também considerado como uma sanção a estas.

Em paralelo à responsabilização administrativa, e independentemente desta, a empresa poderá ser responsabilizada judicialmente pela prática dos mesmos atos ilícitos dispostos na Lei Anticorrupção. Em regra, a persecução judicial será acompanhada pela possibilidade de imposições de sanções mais graves, como a dissolução compulsória da sociedade empresarial, por exemplo.

Dessa maneira, inegavelmente, a LAC inaugura uma junção perigosa, que pode ser fonte de punições arbitrárias e desarrazoáveis: ilícitos de tipicidade aberta (conduta), inexigibilidade de dano ao erário para configuração do ilícito (ilícito de perigo) e, ainda, responsabilidade objetiva entre a conduta e o resultado, devendo-se, a princípio, haver a configuração apenas do nexo causal entre estes.

Além de apresentar esses aspectos gerais da LAC, que nos remetem à hipótese inicial, é mister analisar o papel que o legislador confere aos programas de integridade, mormente a partir da edição do Decreto 8.420/2015. Esse se notabiliza, entre outras coisas, por clarificar o papel do compliance e por tentar uniformizar a aplicação da Lei 12.846/2013, principalmente no que tange ao cálculo da multa sancionadora.

A Lei Anticorrupção, apesar de prever o compliance como atenuante à multa aplicada, não se aprofundou nas minúcias do significado deste. Dessa maneira, surgiram diversos questionamentos sobre como um compliance deveria ser estruturado e sobre quais parâmetros deveriam ser utilizados para se aferir a efetividade de um programa de integridade.

Por conseguinte, o Decreto surgiu, concomitantemente, com o objetivo de afastar a aplicação da atenuante diante de programas de integridade simbólicos e com o objetivo de definir parâmetros para se aferir a qualidade e efetividade desses programas. Dessa maneira, o Capítulo IV do Decreto se dedica a apresentar esses parâmetros, positivando, de grande maneira, os pilares de um compliance efetivo apresentado pela doutrina ${ }^{36}$ e pelo direito comparado ${ }^{37}$.

36. SERPA, Alexandre da Cunha. Op. cit. O autor prevê, e desenvolve ao longo da obra, nove pilares que devem compor um compliance efetivo: 1) política de avaliação de riscos e política de respostas aos ricos avaliados; 2) clarificação dos procedimentos e das políticas de conduta da empresa; 3) suporte da Alta Administração; 4) comunicação aos empregados e Treinamento contínuo destes; 5) due dilligence de terceiros; 6) monitoramento e auditoria do funcionamento do programa de integridade; 7) mecanismos de reporte às denúncias anônimas e confidenciais; 8) investigação de, e respostas para,

Rodrigues, Matheus Vinicius Aguiar. No combate à corrupção empresarial, como incentivar normativamente a implementação efetiva do compliance?

Revista de Direito Administrativo, Infraestrutura, Regulação e Compliance n. 13. ano 4. p. 221-249. São Paulo: Ed. RT, abr.-jun. 2020. 
Ademais, o Decreto dispõe sobre a dosimetria da multa a ser aplicada na decisão sancionadora. Em síntese, esta será equivalente ao somatório dos percentuais das agravantes, diminuindo-se pelo somatório das atenuantes ${ }^{38}$. Nesse sentido, pode se extrair a seguinte tabela:

Tabela 1: Dosimetria da multa no âmbito federal

\begin{tabular}{|c|c|}
\hline \multicolumn{2}{|c|}{ Dosimetria da multa sancionadora (art. $6^{\circ}, \mathrm{I}$, da Lei $12.846 / 2013$ ) } \\
\hline $\begin{array}{l}\text { Agravantes (art. } 17 \text { do } \\
\text { Decreto } 4.820 / 2015 \text { ) }\end{array}$ & $\begin{array}{l}\text { Atenuantes (art. } 18 \text { do } \\
\text { Decreto } 4.280 / 2015 \text { ) }\end{array}$ \\
\hline $1 \%$ a $2,5 \%$ - Continuidade delitiva & $1 \%$ - Se a infração não se consumar \\
\hline $\begin{array}{l}1 \% \text { a } 2,5 \% \text { - Tolerância ou ciência do cor- } \\
\text { po diretivo da pessoa jurídica }\end{array}$ & 1,5\% - Ressarcimento dos danos causados \\
\hline $\begin{array}{l}\text { 1\% a } 4 \% \text { - Interrupção no fornecimento } \\
\text { de serviço público ou na execução da obra } \\
\text { contratada }\end{array}$ & $\begin{array}{l}1 \% \text { a } 1,5 \% \text { - Grau de colaboração da em- } \\
\text { presa com a investigação e apuração do } \\
\text { ato lesivo }\end{array}$ \\
\hline $\begin{array}{l}1 \% \text { - Situação econômica positiva da em- } \\
\text { presa }\end{array}$ & $2 \%$-Em caso de comunicação espontânea \\
\hline $\begin{array}{l}\text { 5\% - Reincidência nos delitos previstos na } \\
\text { Lei Anticorrupção, dentro do período de } \\
\text { cinco anos }\end{array}$ & $\begin{array}{l}1 \% \text { a } 4 \% \text { - Existência de um programa de } \\
\text { integridade, conforme os parâmetros es- } \\
\text { tabelecidos no Decreto } 4.280 / 2015\end{array}$ \\
\hline $\begin{array}{l}1 \% \text { a } 5 \% \text { - A depender do valor total do } \\
\text { contrato mantido ou que a empresa pre- } \\
\text { tendia manter, com o órgão lesado, na data } \\
\text { da prática do ato lesivo }\end{array}$ & \\
\hline
\end{tabular}

Fonte: adaptado do Decreto 4.520/2015.

condutas inconsistentes com o objetivo do programa de integridade; 9) política de atualização contínua do compliance.

37. U.S. Sentencing Commission's Organizational Guidelines (1991) prevê os seguintes parâmetros para se avaliar a efetividade de um programa de compliance: "1) oversight by high-level personnel; 2) due Care in delegating substantial discretionary authority; 3) effective Communication to all levels of employees; 4) reasonable steps to achieve compliance, which include systems for monitoring, auditing, and reporting suspected wrongdoing without fear of reprisal; 5) consistent enforcement of compliance standards including disciplinary mechanisms; 6) reasonable steps to respond to and prevent further similar offenses upon detection of a violation". Disponivel em: [www.ussc.gov/ sites/default/files/pdf/training/organizational-guidelines/ORGOVERVIEW.pdf]. Acesso em: 06.06.2018.

38. Percentual do Faturamento Bruto a ser aplicado como Multa (art. $6^{\circ}$, I, da Lei 12.846/ 2013) $=$ Soma das Agravantes (art. 17 do Decreto 4.820/2015) - Soma das atenuantes (art. 18 do Decreto 4.820/2015).

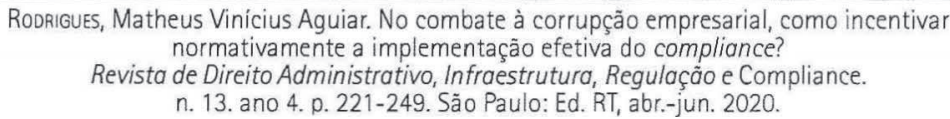


Logo, resta claro o papel do compliance na responsabilização objetiva da pessoa jurídica: trata-se apenas de uma possível atenuante a ser aplicada na dosimetria da multa sancionadora, no percentual de 1 a $4 \%$ do faturamento bruto do último exercício anterior ao da instrução do processo administrativo.

Uma vez apresentado o atual papel jurídico dado pelo legislador ao instituto, cabe se indagar sobre o cálculo econômico para sua viabilidade e sua implantação, sobretudo porque, a partir da próxima fase, buscar-se-á perquirir incentivos normativos para a implementação dos programas de integridade.

Decerto, há um custo de transação na implementação de um compliance efetivo, à luz de todos os parâmetros já suscitados. Economicamente, o compliance só será viável quando os custos para sua implementação e para sua manutenção não se sobreporem aos potenciais benefícios dele advindos.

$\mathrm{E}$, em síntese, a doutrina ${ }^{39}$ aponta quatro benefícios: os programas de integridade, ao promover uma cultura empresarial ética que propicie o respeito à legislação: 1) minorarão os riscos de prática de atos ilícitos e, por consequência, evitarão sanções às empresas; como já ressaltado, uma vez configurada a responsabilidade objetiva da empresa pela prática do ilícito; 2) reduzirão eventuais penalidades aplicadas ${ }^{40}$; 3) facilitarão a realização de acordos com as autoridades regulatórias, como o Acordo de Leniência e o Termo de Compromisso de Cessação (TCC); e, por fim, trarão 4) vantagens quanto à reputação e à competição para a empresa.

Destaca-se, ainda, a importância do compliance diante da explosão regulatória no século XXI. Paulatinamente, as empresas passaram a lidar com numerosas e complexas leis, que, certamente, geram custos econômicos e riscos regulatórios a serem monitorados. Esse cenário é ilustrado, anualmente, pelo relatório Cost of Compliance, da Thomson Reuters Regulatory Intelligent. Durante o ano de 2017, por exemplo, o relatório apontou a existência de 56.321 alertas regulatórios perante o monitoramento de 900 órgãos reguladores globais. Em cada 7 minutos, há um novo alerta regulatório ${ }^{41}$ :

39. MENDES, Franciso Schertel; DE CARVALHO, Vinícius Marques. Op. cit., p. 36-43; e CASTRO, Marina Grimaldi de. O programa de compliance corporativa. In: DUTRA, Licoln Zub (Org.). Compliance no ordenamento jurídico brasileiro. Curitiba: Juruá, 2018. p.172-174.

40. Além da Lei Anticorrupção, diversos outros estatutos jurídicos adotam o compliance como atenuante a sanções, como no Direito da Concorrência, diante das multas e das contribuições pecuniárias aplicadas no CADE, nos Termos de Compromisso de Cessação (TCC), à luz da aplicação da Lei 12.529/2011.

41. ENGLISH, Stacey; HAMMOND, Susannah. Cost of Compliance 2018. Thomson Reuters. 2018. Disponível em: [https://risk.thomsonreuters.com/content/dam/openweb/documents/pdf/risk/report/cost-of-compliance-special-report-2018.pdf]. Acesso em: 15.07.2018.

Rodrigues, Matheus Vinícius Aguiar. No combate à corrupção empresarial, como incentivar normativamente a implementação efetiva do compliance?

Revista de Direito Administrativo, Infraestrutura, Regulação e Compliance. n. 13. ano 4. p. 221-249. São Paulo: Ed. RT, abr.-jun. 2020. 
Gráfico 1: Risco regulatório
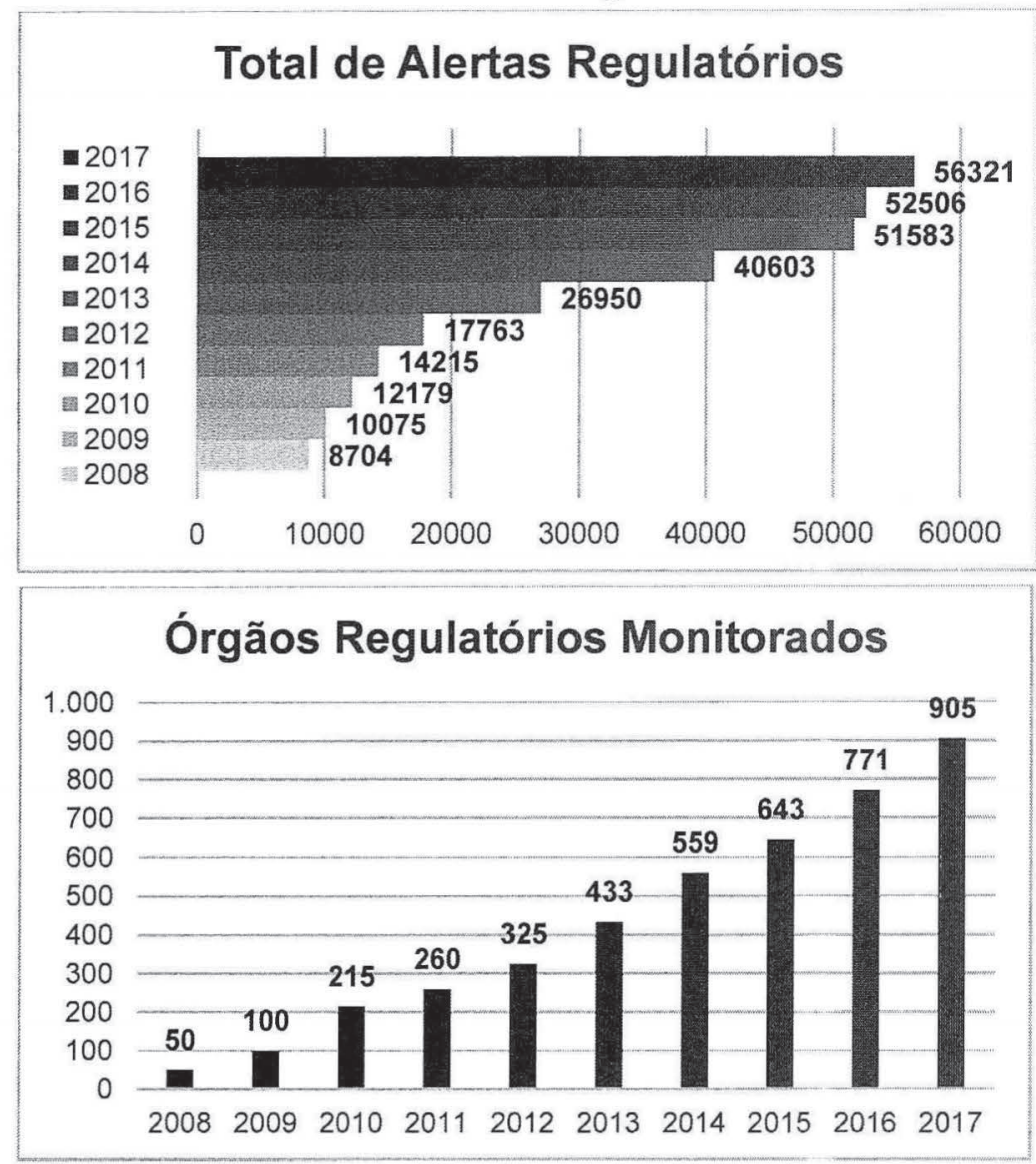

Fonte: adaptado de ENGLISH, Stacey; HAMMOND, Susannah (2018, p. 16).

Nesse contexto, a gestão de riscos inerente à implementação de um programa de integridade adquire proeminência. À luz desses benefícios que o compliance proporciona às empresas, visto como incentivos à autorregulação regulada, a efetivação desses programas de integridade passou a ser entendida como uma necessidade. Uma necessidade empresarial, sobretudo visando à perenidade e ao probo desenvolvimento das atividades da empresa, e uma necessidade do próprio Estado, porquanto, ao fim e ao cabo, a autorregulação das empresas externalizaria consequências positivas a toda sociedade $e^{42}$.

42. Nesse sentido, destaca-se: "Deve-se destacar que não há como desvincular o desenvolvimento das organizações do desenvolvimento da própria sociedade, sendo um espelho

Rodrigues, Matheus Vinicius Aguiar. No combate à corrupção empresarial, como incentivar normativamente a implementação efetiva do compliance?

Revista de Direito Administrativo, Infraestrutura, Regulação e Compliance.

n. 13. ano 4. p. 221-249. São Paulo: Ed. RT, abr.-jun. 2020. 
Não obstante, mesmo diante dessa imprescindibilidade de se implementar efetivamente o compliance, cada vez mais, premente às empresas ${ }^{43}$ e ao próprio Estado, o compliance ainda não se tornou regra no Brasil ${ }^{44}$. Isso requer uma reanálise das estruturas de incentivos à adoção desses programas de integridade ${ }^{45}$.

do outro. Portanto, a evolução em um desses setores influenciará o outro, pois estará demonstrando o aprendizado e o desejo de mudança dos atores. (...) Portanto, a implantação de uma política de Compliance auxilia não somente no desenvolvimento da empresa, mas principalmente da sociedade, porque os comportamentos adotados em cada seara tendem a ser copiados e replicados, estimulando a transparência, a ética e a confiança em qualquer relação, bases para uma verdadeira sustentabilidade" (RIBEIRO, Marcia Carla Pereira; DINIZ, Patrícia Dittrich Ferreira. Compliance e Lei Anticorrupção nas empresas. Revista de Informação Legislativa, Brasília, ano 52, n. 205, p. 98-103, jan.-mar. 2015, grifo meu).

43. Não se pode olvidar da existência do debate acerca da necessidade ou da obrigatoriedade do compliance, mormente após as edições das seguintes leis estaduais: a Lei 7.753/2017, do Rio de Janeiro, e a Lei 6.612/2018, do Distrito Federal, já referidas neste trabalho. O autor deste trabalho, não obstante, entende que as referidas leis são inconstitucionais, por violação expressa à competência privativa da União para editar normas gerais de licitação e contratos administrativos (art. 22, XXVII, Constituição Federal/1988).

44. Essa realidade advém, sobretudo, da complexidade do regime de normas de conformidade. Em estudo intitulado The Compliance Complexity Index, realizado pela TMF Group, o Brasil figurou na sétima colocação entre os países que possuem uma maior complexidade para a implementação efetiva de um programa de integridade. O estudo apontou: "O Brasil se classificou como um dos piores países do Compliance Complexity Index esse ano, sobretudo porque há diversas mudanças processuais que podem complicar os negócios jurídicos. Embora não tenha tido mudanças em grande escala nos últimos meses, houve diversas mudanças no procedimento de registro de empresas na Junta Comercial, na Receita Federal e nas prefeituras que aumentaram, até certo ponto, a burocracia no setor. A combinação do tumultuado cenário político e o ano eleitoral fazem com que o futuro da complexidade econômica do Brasil seja bastante incerto" (p. 18, tradução livre). Disponivel em: [www.tmf-group.com/en/news-insights/publications/2018/the-compliance-complexity-index/l. Acesso em: 20.07.2018.

45. Na análise dessa estrutura de incentivos, não se pode olvidar de citar as desvantagens oriundas do compliance. Nesse sentido, cito a obra de Francis Rafael Beck que, didaticamente, aponta que: "Por outro lado, as vantagens não estão isentas de desvantagens, especialmente: a) possível engessamento da produção, pela adoção de padrão estrito de cumprimento de deveres; b) ampliação do âmbito de responsabilização ainda no âmbito empresarial (independente de garantias processuais penais); c) aumento dos custos de transação, notadamente, pela existência do Departamento de Compliance [...]; d) indefinição a respeito da aplicação judicial dos programas de compliance, tanto em razão da ausência de moldura legal para a estruturação dos programas quando pelas

Rodrigues, Matheus Vinicius Aguiar. No combate à corrupção empresarial, como incentivar normativamente a implementação efetiva do compliance?

Revista de Direito Administrativo, Infraestrutura, Regulaçấo e Compliance. n. 13. ano 4. p. 221-249. São Paulo: Ed. RT, abr.-jun. 2020. 
Nesse sentido, destaco a Avaliação do Nível de Maturidade de Compliance, no Brasil, em $2017^{46}$, elaborada pela empresa de consultoria e auditoria Protiviti, que apresentou os seguintes resultados:

Gráfico 2: Maturidade de compliance no Brasil

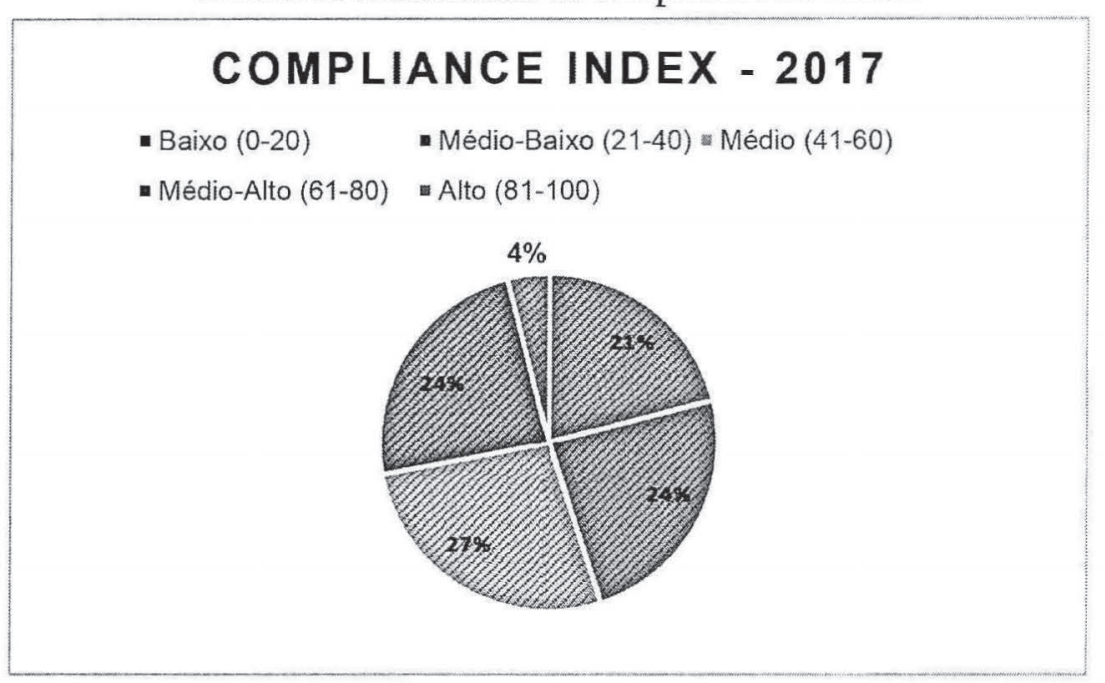

Fonte: adaptado de PROTIVITI, p. 6.

Dessa maneira, a pesquisa demonstra que apenas $4 \%$ das empresas brasileiras possuem um programa de compliance efetivo, que possa prevenir e detectar atos de corrupção. Por outro lado, cerca de $45 \%$ das organizações brasileiras estão altamente expostas a riscos de corrupção, não direcionando quase nenhum esforço para coibi-los na persecução de um ambiente ético.

É a partir dessa realidade, apresentada nessa primeira fase, que introduzimos e restringimos nosso problema: "como gerar incentivos normativos à adoção do compliance pelas sociedades empresariais?". No exercício de reanalisarmos a estrutura de incentivos presente nos instrumentos normativos e, ainda, ao partir da

dúvidas no que diz respeito à interpretação judicial que receberá no Judiciário brasileiro" (BECK, Francis Rafael. A dupla face do criminal compliance: da expetativa de afastamento e mitigação da responsabilidade penal à possibilidade de incremento punitivo. In: DUTRA, Licoln Zub (Org.). Compliance no ordenamento jurídico brasileiro. Curitiba:Juruá, 2018. p. 79).

46. PROTIVITI. Nível de maturidade em compliance nas empresas brasileiras. 2017. Disponível em: [www.protiviti.com/sites/default/files/infografico_-_nivel_de_maturidade_em_compliance_nas_empresas_brasileiras.pdf]. Acesso em: 20.07.2018.

Rodrigues, Matheus Vinicius Aguiar. No combate à corrupção empresarial, como incentivar normativamente a implementação efetiva do compliance?

n. 13. ano 4. p. 221-249. São Paulo: Ed. RT, abr.-jun. 2020. 
segunda hipótese apresentada na introdução dessa obra ("[que] a LAC não adota um parâmetro de imputação e culpabilidade, na responsabilização da pessoa jurídica, que incentive, da forma mais efetiva possível, a autorregulação empresarial"), iremos propor duas soluções normativas, com fulcro nos pressupostos teóricos a serem apresentados na próxima fase, que julgamos responder adequadamente às hipóteses apresentadas até aqui.

O compliance anticorrupção precisa ser a regra no jogo do combate à corrupção, e, para isso, propomos duas soluções normativas as quais acreditamos que possam ser vetor no recrudescimento da importância dos programas de integridade, em abstrato, e ser vetor na implementação efetiva do compliance nas organizações empresariais.

\section{DESCRIÇÃO DA SOLUÇÃO}

Não há incentivos normativos simples, sobretudo diante do capitalismo de compadrio (crony capitalism ${ }^{47}$ ) e da corrupção endêmica na qual, historicamente, o Brasil está imerso. Isto posto, não nos limitaremos a apresentar soluções fáceis que supostamente possam incentivar a adoção de programas de integridade.

Dessa forma, soluções, como aumentar o percentual mínimo conferido à presença de um programa de integridade efetivo, na dosimetria da multa-sanção, seja por meio de uma alteração no Decreto 8.420/2015, em nível do governo federal, seja como sugestão à regulamentação da Lei 12.846/2013, no âmbito estadual ou municipal, devem ser vistas com cautela ${ }^{48}$. Primeiramente, porque o nosso problema (o compliance efetivo não ser uma realidade nas organizações brasileiras) não se circunscreve apenas a uma variável econômica. Em seguida, porque se trata de uma solução normativa que requer necessariamente uma pesquisa empírica e econômica a médio e longo prazo, sob pena de ser uma solução que represente uma inferência indutiva com pouco grau de probabilidade na verdade da conclusão.

Assim como ressaltado na primeira fase, busca-se perquirir incentivos normativos que possam responder adequadamente a nossas hipóteses iniciais. Eles

47. PAUlA, Marco Aurélio Borges de. Op. cit., p. 23.

48. Trata-se, por exemplo, de uma das soluções apresentadas na obra de Jorge Hage (HAGE, Jorge. Evolução e perspectivas do combate à corrupção no Brasil. In: PAULA, Marco Aurélio Borges de; CASTRO, Rodrigo Pironti Aguirre de (Coord.). Compliance, gestão de riscos e combate à corrupção: integridade para o desenvolvimento. Belo Horizonte: Fórum, 2018. p. 325).

RoDrigues, Matheus Vinicius Aguiar. No combate à corrupção empresarial, como incentivar normativamente a implementação efetiva do compliance? Revista de Direito Administrativo, Infraestrutura, Regulação e Compliance n. 13. ano 4. p. 221-249. São Paulo: Ed. RT, abr.-jun. 2020. 
perpassam, inevitavelmente, pela persecução dos fundamentos adequados para a configuração da responsabilidade jurídica das empresas na LAC e pelo papel conferido ao compliance nesse process $0^{49}$. Nessa análise, ao final, apresentaremos um desses possíveis incentivos normativos.

\subsection{Fundamento adequado para a responsabilidade jurídica das empresas na LAC: interpretação conforme à Constituição Federal de 1988 na AD/ 5.261}

O instituto da responsabilidade jurídica sempre gera uma discussão de "se", "quem", "por que" e "como". Na esfera punitiva do Estado, seja no Direito Administrativo Sancionador, seja no Direito Penal, há duas alternativas para a punição das pessoas jurídicas.

Na primeira opção, pune-se a pessoa jurídica por fato próprio - seja a partir da criação de um sistema específico de culpabilidade, principalmente diante da percepção de uma falha estrutural na organização que incrementou o risco à prática de um ato ilícito (teoria do defeito de organização), seja a partir da criação de um conceito específico de autoria ("domínio sistêmico-funcional da organização"), que obrigaria as organizações a antecipar e a prevenir os riscos inerentes à sua atividade, com a adoção de medidas de governança corporativa que possam assegurar o regular e lícito desenvolvimento das atividades da empresa ${ }^{50}$.

49. Nesse sentido, destaco: "A discussão sobre a repercussão dos programas de compliance na responsabilização punitiva das pessoas jurídicas não diz respeito apenas à questão de incentivos para a implementação das referidas iniciativas, mas também aos próprios fundamentos para a punição das pessoas jurídicas" (FRAZÃO, Ana. Direito da concorrência: pressupostos e perspectivas. São Paulo: Saraiva, 2017. p. 282-283).

50. Sobre o tema, destaco as consideraçōes de José Luis de la Cuesta: "A observação anterior, embora não exaustiva, levou importantes doutrinadores a estudar a maneira e as condições sob as quais se poderia conciliar uma intervenção penal sobre as pessoas jurídicas, respeitando-se os princípios tradicionais do Direito Penal. Assim, na Alemanha, autores relevantes, como Hirsch, Jakobs ou Lampe, propõem uma reconfiguração das categorias de autoria e culpabilidade compativeis com as pessoas jurídicas. Neste campo se destaca o marco doutrinário, no Direito Penal comparado, contribuições como as de Achenbach, Brender, Heine, Schroth, Tiedemann ou Volk. Destes, ressalta-se a proposta de K. Tiedemann de estruturar uma culpabilidade específica às pessoas jurídicas sob as bases do 'defeito da organização', proposta esta que teve uma especial incidência no nosso âmbito cultural. Mais desenvolvida e recente, a proposta de G. Herine merece igualmente uma atenção particular (...)" (tradução livre, grifos nossos). Posteriormente, ao analisar as propostas de K. Tiedemann e G. Heine, o autor da obra ressalta: "[Para K. Tiedemann] a única alternativa possível é propor uma entendimento específico de culpabilidade às pessoas jurídicas. Este conceito de culpa, seja social, seja jurídico, pode

Rodrigues, Matheus Vinicius Aguiar. No combate à corrupção empresarial, como incentivar normativamente a implementação efetiva do compliance?

Revista de Direito Administrativo, Infraestrutura, Regulação e Compliance.

n. 13. ano 4. p. 221-249. São Paulo: Ed. RT, abr.-jun. 2020. 
A responsabilidade jurídica por fato próprio (strict liability) é incorporada em legislações penais de países, como Suíça e Austrália, nas quais se punem as organizações pela ausência de uma "cultura corporativa requerida pela lei" ${ }^{11}$ ou, ainda, pela configuração do "defeito de organização empresarial"

Na segunda opção, adotada pelo legislador na LAC, imputa-se à pessoa jurídica, de forma automática, fato de "terceiro", ou seja, a conduta de terceiros que agem em nome da pessoa jurídica com o objetivo de beneficiar esta. Trata-se de

ser baseado, na opinião de K. Tiedemann, na detecção de um defeito organizacional, que consiste na omissão, por parte de seus órgãos ou representantes, em relação às preocupações ou aos mecanismos institucionais que possam ser precisos no controle dos riscos à prática de ilícitos no seio da atividade habitual ou estatutária da organização. Uma vez constatada a produção de um ato ilícito, a existência desse defeito organizacional seria suficiente para permitir a intervenção penal contra a pessoa jurídica, uma intervenção que não dependeria da constatação de um indivíduo executando diretamente o ato típico e ilícito, nem da sua possível culpabilidade individual" (tradução livre, grifos nossos). Já na proposição de $\mathrm{G}$. Heine, que ressignifica o instituto da autoria na imputação às pessoas jurídicas, José Luis de la Cuesta destaca: "se a autoria, quando se trata de pessoas físicas, é regida pelo domínio do fato, quando se trata de pessoas jurídicas, esse conceito deve ser substituído pelo 'domínio sistêmico-funcional da organização', que exige que a entidade antecipe e impeça riscos inerentes a sua operação, por meio da ações de medidas horizontais e verticais, pela manutenção dos níveis de integridade exigidos e por meio de inspeções internas que possam garantir o funcionamento de controle e o respeito às exigências de qualidade. (...) Quanto à culpabilidade, G. Heine entende que a culpabilidade específica da pessoa jurídica é a 'culpabilidade pela direção da empresa' (Betriebsführungsschuld) (...)" (CUESTA, J. L. Una "nueva" línea de intervención penal: el Derecho Penal de las personas jurídicas. In: MESSUTI, A; SANPEDRO ARRUBLA, J. A. La Administración de Justicia en los albores del tercer milenio. Buenos Aires: Editorial Universidad, 2001. p 70-71, tradução livre, grifos nossos).

51. Segundo o Australian Criminal Code Act 1995, Part. 2.5, Division 12, 12.3, (2), (c) e (d): "12.1 (2) A body corporate may be found guilty of any offence, including one punishable by imprisonment. (...) 12.3 Fault elements other than negligence (...) (2) The means by which such an authorisation or permission may be established include: (c) proving that a corporate culture existed within the body corporate that directed, encouraged, tolerated or led to non-compliance with the relevant provision; or (d) proving that the body corporate failed to create and maintain a corporate culture that required compliance with the relevant provision." (AUSTRÁLIA. Criminal Code Act 1995. Disponível em: [www8.austlii. edu.au/cgi-bin/viewdoc/au/legis/cth/consol_act/cca1995115/schl.html]. Acesso em: 22.07.2018).

52. Nesse sentido, art. 102 do Swiss Criminal Code; Title Seven: Corporate Criminal Liabily (SUÍÇA. Swiss Criminal Code. Disponível em: [www.admin.ch/opc/en/classified-compilation/19370083/201803010000/311.0.pdf]. Acesso em: 22.07.2018).

RodRIgues, Matheus Vinícius Aguiar. No combate à corrupção empresarial, como incentivar normativamente a implementação efetiva do compliance?

Revista de Direito Administrativo, Infraestrutura, Regulaçấo e Compliance. n. 13. ano 4. p. 221-249. São Paulo: Ed. RT, abr.-jun. 2020. 
uma espécie de responsabilidade objetiva, fundada na teoria da vicarious liability ("let the superior answer"), aplicada no âmbito punitivo ${ }^{53}$.

Como já ressaltado na primeira fase, essa escolha legislativa provocou intensos debates já no processo legislativo para a aprovação do Projeto de Lei 6.826-A, inclusive com emendas ao projeto que suscitavam a inconstitucionalidade dessa responsabilização objetiva na seara punitiva.

Essa celeuma jurídica deu ensejo, posteriormente, ao ajuizamento da Ação Direta de Inconstitucionalidade 5.261/DF, pelo Partido Social Liberal (PSL), que sustenta que o ordenamento constitucional i) não admitiria a responsabilização e aplicação de sanções de forma objetiva, sem a análise do dolo ou da culpa, ii) não admitiria a responsabilidade da pessoa jurídica pela prática de atos por terceiro, em respeito ao princípio da intranscendência das penas, e, por fim, iii) a teoria do risco integral, adotado pela LAC, violaria os princípio da razoabilidade e proporcionalidade. Dessa maneira, pugna-se pela violação aos arts. $1^{\circ}$, inciso III, e $5^{\circ}$, incisos XLV, XLVI e LIII, da Constituição Federal/1988.

É nesse sentido que este trabalho entende que um dos incentivos normativos à implementação efetiva do compliance perpassa por uma interpretação conforme à Constituição Federal/1988 da responsabilidade objetiva prevista na LAC, sobretudo para evitar arbitrariedades e punições desarrazoáveis em função da junção perigosa que a LAC estabelece, conforme já analisado neste trabalho.

Uma vez inserida na esfera no Direito Administrativo Sancionador, às pessoas jurídicas na responsabilização devem ser garantidas, dentro da flexibilidade que caracteriza essa esfera administrativa, as garantias típicas do Direito Penal ${ }^{54-55}$, sobretudo porque ambos se inserem dentro do braço punitivo estatal.

Dessa forma, não se deve cogitar a aplicação de sanções administrativas (punibilidade) sem a presença de um ato típico, ilícito e culpável $^{56}$. Isto posto, i) não há sanção sem a reprovabilidade da conduta (culpabilidade), bem como não se deve confundir o juízo de imputação objetivo/automático (vicarious liability) com o próprio juízo de mérito e reprovabilidade da conduta, que é pressuposto para a punibilidade.

53. FRAZÃO, Ana. Programas de compliance e critérios de responsabilização de pessoas jurídicas por ilícitos administrativos cit., p. 7.

54. Ibidem, p. 2.

55. NIETO, Alejandro. Derecho Administrativo Sancionador. Madrid: Tecnos, 2006. p. 165171 .

56. CUNHA, Rogério Sanches. Manual de direito penal: parte geral. 5. ed. Salvador:JusPodivm, 2017. p. 195.

Rodrigues, Matheus Vinicius Aguiar. No combate à corrupção empresarial, como incentivar normativamente a implementação efetiva do compliance?

Revista de Direito Administrativo, Infraestrutura, Regulação e Compliance.

n. 13. ano 4. p. 221-249. São Paulo: Ed. RT, abr.-jun. 2020. 
Essa culpabilidade coorporativa: i) aproxima a vicarious liability da responsabilidade jurídica das organizações por fato próprio; ii) limita a movimentação da perigosa máquina punitiva estatal, diante da elevada possibilidade de punições desarrazoáveis, com ilícitos de tipicidade aberta e de perigo abstrato e com vários intérpretes/aplicadores da lei; iii) funda a punibilidade das empresas em bases que julgamos constitucionalmente adequadas ${ }^{57}$; iv) confere aos programas de integridade importância-chave nessa análise probatória ${ }^{58}$; e, por fim, v) possui o condão de se apresentar como vetor no combate à corrupção a partir de um novo paradigma, que foge da integridade individual e interna das empresas, aproximando-se da teoria da ação coletiva, como será explicado logo mais.

Além disso, ressalta-se que essa interpretação na responsabilidade jurídica das organizações não se coaduna com a impunidade. Como apresentado na primeira fase, apenas $4 \%$ das empresas brasileiras possuem um programa de integridade efetivo na prevenção e detecção de atos ilícitos e, dessa maneira, seriam estas que poderiam demonstrar, suficientemente, que a organização não concorreu, de forma comissiva ou omissiva, à prática do ilícito. Empiricamente, portanto, não há correlação entre a interpretação aqui defendida e a impunidade dessas empresas que concorrem à prática de ilícitos.

Nessa análise probatória da efetividade do compliance, há um importante espaço para se inaugurar um novo paradigma no combate à corrupção, que pode ser uma injunção dessa interpretação a ser dada pelo Supremo Tribunal Federal na ADI $5.261 \mathrm{ou}$, ainda, ser uma matéria de disposição legislativa estadual ou municipal, na regulamentação da Lei 12.846/2013.

57. Nesse sentido, ainda destaco: "O que se pode compreender da novel legislação é que a existência e o funcionamento efetivo do seu sistema de integridade é a chave para compreender aquilo que o artigo $2^{\circ}$ denominou responsabilidade objetiva: a organização empresarial deve possuir standards de comportamento e de estruturas, inclusive após a constatação do ilícito, que permitam concluir que o ato lesivo decorreu de um ato individual e isolado de determinado colaborador. [...] Fora dessa realidade, estar-se-á admitindo o apenamento contrário ao direito, porque a própria punição não terá referência a um comportamento negativo de quem a suportará, seja porque a entidade não merece a punição, seja porque essa punição não trará qualquer exemplo para a sociedade, porque sinaliza arbítrio" (TAMASAUSKAS, Igor Sant'Anna; BOTTINI, Pierpaolo Cruz. A interpretação constitucional possível da responsabilidade objetiva na lei anticorrupção. Revista dos Tribunais, São Paulo, v. 103, n. 947, p. 142, set. 2014.).

58. "Sob o foco da pessoa jurídica, os programas de cumprimento poderiam ser vistos como um elemento chave para fundamentar a responsabilidade empresarial, tanto como elemento constitutivo do injusto (não adoção ou adoção deficiente) quanto como elemento configurador da culpabilidade empresarial" (BECK, Francis Rafael. Op. cit., p. 87).

RODRIGUES, Matheus Vinícius Aguiar. No combate à corrupção empresarial, como incentivar normativamente a implementação efetiva do compliance?

Revista de Direito Administrativo, Infraestrutura, Regulação e Compliance. n. 13. ano 4. p. 221-249. São Paulo: Ed. RT, abr.-jun. 2020. 
À luz da realidade disposta na primeira fase, que nos coloca em um cenário endêmico e com uma legislação anticorrupção recente e não consolidada, o enfrentamento à corrupção no plano coletivo adquire importância premente. A doutrina ${ }^{59}$ defende a efetividade de diversas ações coletivas, sejam ações controladas, sejam ações independentes, no combate à corrupção, sobretudo aquelas que se incluem nas categorias de ações coletivas dispostas no Guia prático para a ação coletiva contra a corrupção ${ }^{60}$, publicado pela ONU em 2008:

Tabela 2: Classificações das ações coletivas

\begin{tabular}{|c|c|c|}
\cline { 2 - 3 } \multicolumn{1}{c|}{} & Compromisso Ético & Enforcement externo \\
\hline Acordos-Curto Prazo & $\begin{array}{c}\text { Declarações } \\
\text { Anticorrupções }\end{array}$ & Pacto de Integridade \\
\hline Iniciativas-Longo Prazo & $\begin{array}{c}\text { Iniciativa baseada em } \\
\text { princípios }\end{array}$ & $\begin{array}{c}\text { Certificações de } \\
\text { Compromissos Empresariais }\end{array}$ \\
\hline
\end{tabular}

Fonte: adaptado de United Nations Global Compact (2015, p. 17).

Essas categorias de ações coletivas são essenciais na formação de cartéis de integridades setoriais ${ }^{61}$, que podem ser essenciais na análise probatória da culpabilidade coorporativa em um processo administrativo sancionador. Atenho-me apenas a uma dessas ações que, concomitantemente, por um lado, corrobora a importância desse paradigma coletivo no combate à corrupção e, por outro, exemplifica a relevância de se perquirir a culpabilidade coorporativa como incentivo normativo ao compliance, a qual seria as certificações de compromissos empresariais.

As certificações de compromissos empresariais, iniciativa em longo prazo que busca promover padrões de ética empresarial em determinado setor ou região,

59. ZENKNER, Marcelo. O papel do setor privado na promoção da integridade nos negócios. In: PAULA, Marco Aurélio Borges de; CASTRO, Rodrigo Pironti Aguirre de (Coord.). Compliance, gestão de riscos e combate à corrupção: integridade para o desenvolvimento. Belo Horizonte: Fórum: 2018. p. 89-119.

60. UNITED NATIONS GLOBAL COMPACT. A Practical Guide for Collective Action against Corruption. New York, 2015. Disponível em: [www.unglobalcompact.org/docs/issues_doc/Anti-Corruption/CollectiveActionExperiencesGlobal.pdf]. Acesso em: 23.07.2018.

61. Nesse sentido, destaco o acordo no setor de saúde que trata de uma espécie de iniciativa baseada em princípios, entre importadores, distribuidores e fabricantes de dispositivos médicos. Disponível em: [www.cmsmedical.com.br/upload/files/Acordo_Setorial_ Portugues2.pdf]. Acesso em: 23.07.2018.

RODRIGUES, Matheus Vinicius Aguiar. No combate à corrupção empresarial, como incentivar normativamente a implementação efetiva do compliance?

Revista de Direito Administrativo, Infraestrutura, Regulação e Compliance. n. 13. ano 4. p. 221-249. São Paulo: Ed. RT, abr.-jun. 2020 
são acompanhadas por um enforcement externo. Em geral, auditorias e monitoramento por órgãos externos são responsáveis pela adesão/certificação à empresa, bem como pela manutenção desta.

Trata-se de uma complexa modalidade de ação coletiva ${ }^{62}$, pois envolve compromissos públicos com práticas de integridade e com estruturas externas rígidas e permanentes de controle e auditoria em relações ao compliance empresarial. Recentemente, essa modalidade se destacou no Brasil diante da criação do Cadastro Nacional de Empresas Comprometidas com a Ética e a Integridade (Cadastro Pró-Ética), gerenciado pelo atual Ministério da Transparência e Controladoria-Geral da União.

Anualmente, o Pró-Ética certifica uma lista de empresa comprometidas com a integridade e com o combate à corrupção, a partir de uma auditoria detalhada e específica da política de compliance adotada pela organização. De um lado, essas empresas que participam do programa recebem um relatório sobre aspectos detalhados do programa de integridade interno e sobre sugestões de melhoria; de outro, apenas algumas delas são certificadas publicamente com a marca Pró-Ética.

Destarte, as ações coletivas, sobretudo aquelas controladas por um enforcement externo, representam mais um indício para se analisar a culpabilidade coorporativa, que poderia afastar a punibilidade das empresas, afastando o compliance do papel coadjuvante de atenuante às multas aplicadas pela LAC. A autorregulação regulada precisa ser regra no combate à corrupção, principalmente a partir de um paradigma coletivo de combate à corrupção, que é importante às peculiaridades brasileiras. Não obstante, o compliance precisa de incentivos normativos, seja pela interpretação conforme à Constituição da responsabilidade objetiva disposta na LAC, seja por uma regulação normativa que confere ao compliance o papel de protagonista em ações coletivas destinadas a combater a corrupção.

\section{ConcLusão}

Deste artigo extraem-se as seguintes conclusões:

1. ao longo deste trabalho, restou latente a importância do cenário internacional nas iniciativas nacionais de combate à corrupção, o que se verificou na edição Lei 12.846/2013 e, ainda, na pressão internacional para criminalizar a corrupção privada. Diante do recrudescimento do combate à corrupção, haverá

62. ZENKNER, Marcelo. Op. cit., p. 113-114.

Rodrigues, Matheus Vinicius Aguiar. No combate à corrupção empresarial, como incentivar normativamente a implementação efetiva do compliance?

Revista de Direito Administrativo, Infraestrutura, Regulação e Compliance. n. 13. ano 4. p. 221-249. São Paulo: Ed. RT, abr.-jun. 2020. 
incentivos à autorregulação privada, o que se constatou desde a edição da Resolução 2.554/1998, do BACEN, a qual determinou às instituições financeiras a criação e a implementação de programas de conformidade às leis aplicáveis ao setor;

2. dessa maneira, observou-se também que o conceito de programas de integridade não se origina na Lei 12.846/2013, embora seja com essa que ganhariam notoriedade, espalhando-se a outros ramos jurídicos e a empresas de diversos setores. O recrudescimento da importância do compliance se insere em um fenômeno que foi apresentado em três momentos: i) o monitoramento e a publicidade de índices criados no combate à corrupção, a partir dos quais adveio a pressão nacional e internacional no aprimoramento legislativo sobre o tema; ii) a produção legislativa sobre o tema, na qual se destaca a Lei 12.846/2013; e, por fim iii) a intensificação institucional na prevenção e deteç̧ão da corrupção, a partir da atuação de diversos órgãos no Brasil;

3. em seguida, apresentou-se a definição de compliance, a partir de uma concepção restrita do termo (compliance anticorrupção). Os programas de integridade foram definidos como uma "ferramenta meio não suficiente" instituída pelo legislador no combate à corrupção empresarial, nos níveis da prevenção e detecção desta;

4. ao se adentrar na análise dos aspectos gerais da Lei 12.848/2013 e no papel conferido ao compliance, explicitaram-se a junção perigosa instituída pelo legislador da responsabilidade objetiva, de ilícitos de tipicidade aberta e de perigo abstrato e, ainda, a competência de diversos órgãos para aplicá-la, na persecução da responsabilidade administrativa e civil da empresa. Além disso, no Decreto 8.420/2015, analisamos o papel do compliance como atenuante à multa sancionadora instituída pela Lei 12.846/2013;

5. posteriormente, ao explicitar e analisar os benefícios do compliance às organizações empresariais, como o monitoramento dos riscos regulatórios, as vantagens econômicas na deteç̧ão da corrupção e, ainda, as vantagens quanto à reputação e à competição da empresa, demonstrou-se que ele não seria uma realidade nas organizações brasileiras. A partir disso, destacou-se a pertinência do nosso problema, reforçando a necessidade de se revisitar a estrutura de incentivos e de custos de transação à implementação efetiva do compliance;

6. restringindo nosso problema aos incentivos normativos, defendeu-se a necessidade de se interpretar constitucionalmente a responsabilidade objetiva instituída na Lei 12.846/2013, à luz de cinco razões: i) a necessidade de se limitar a movimentação da máquina punitiva estatal, diante da junção perigosa instituída na LAC que dá azo a punições desarrazoáveis; ii) a fundação da responsabilidade jurídica das empresas em bases constitucionalmente adequadas, principalmente

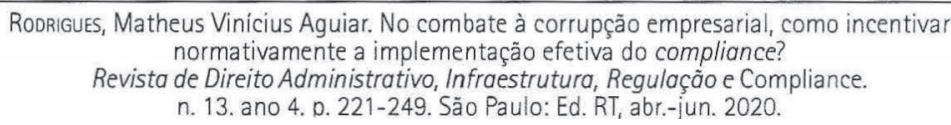


diante da necessidade de se garantir princípios penais basilares ao Direito Administrativo Sancionador; iii) o abandono do papel coadjuvante pelos programas de integridade, como atenuantes à multa sancionadora, para um papel central na análise probatória da culpabilidade coorporativa; iv) a análise de uma culpabilidade coorporativa para a aproximação da vicarius liability com a responsabilidade jurídica das organizações por fato próprio, apontada como constitucionalmente adequada; e, por fim, v) o condão de vetor no combate à corrupção, no contexto probatório da efetividade do compliance, a partir de um paradigma coletivo, com a possibilidade de instituição em regulamentação estadual da Lei 12.846/2013 ou, ainda, como uma consequência/remédio dessa decisão judicial.

\section{REFERÊNCIAS}

BECK, Francis Rafael. A dupla face do criminal compliance: da expetativa de afastamento e mitigação da responsabilidade penal à possibilidade de incremento punitivo. In: DUTRA, Licoln Zub (Org.). Compliance no ordenamento jurídico brasileiro. Curitiba: Juruá, 2018.

CASTRO, Marina Grimaldi de. O programa de compliance corporativa. In: DUTRA, Licoln Zub (Org.). Compliance no ordenamento jurídico brasileiro. Curitiba: Juruá, 2018.

CUESTA, J. L. Una "nueva" línea de intervención penal: el Derecho Penal de las personas jurídicas. In: MESSUTI, A; SANPEDRO ARRUBLA, J. A. La Administración de Justicia en los albores del tercer milenio. Buenos Aires: Editorial Universidad, 2001.

CUNHA, Rogério Sanches. Manual de direito penal: parte geral. 5. ed. Salvador: JusPodivm, 2017.

DECOMTEC/FIESP. Relatório Corrupção: custos econômicos e propostas de combate. 2010. Disponívelem: [www.fiesp.com.br/arquivo-download/?id=2021] . Acesso em: 02.06.2018.

DIPP, Gilson; CASTILHO, Manoel L. Volkmer de. Comentários sobre a Lei anticorrupção. São Paulo: Saraiva, 2016.

ENGLISH, Stacey; HAMMOND, Susannah. Cost of Compliance 2018. Thomson Reuters. 2018. Disponivel em: [https://risk.thomsonreuters.com/content/ dam/openweb/documents/pdf/risk/report/cost-of-compliance-special-report-2018.pdf]. Acesso em: 15.07.2018.

FRAZÃO, Ana. Direito da concorrência: pressupostos e perspectivas. São Paulo: Saraiva, 2017.

FRAZÃO, Ana. Programas de compliance e critérios de responsabilização de pessoas jurídicas por ilícitos administrativos. In: ROSSETTI, Maristela Abla; PITTA, Andre Grunspun (Coord.). Governança corporativa: avanços e retrocessos. São Paulo: Quartier Latin, 2017.

Rodrigues, Matheus Vinícius Aguiar. No combate à corrupção empresarial, como incentivar normativamente a implementação efetiva do compliance?

Revista de Direito Administrativo, Infraestrutura, Regulação e Compliance. n. 13. ano 4. p. 221-249. São Paulo: Ed. RT, abr.-jun. 2020. 
GIANNETI, Eduardo. Vícios privados, benefícios públicos? A ética na riqueza das nações. São Paulo: Companhia de Bolso, 2007.

HAGE, Jorge. Evolução e perspectivas do combate à corrupção no Brasil. In: PAULA, Marco Aurélio Borges de; CASTRO, Rodrigo Pironti Aguirre de (Coord.). Compliance, gestão de riscos e combate à corrupção: integridade para o desenvolvimento. Belo Horizonte: Fórum, 2018.

MARINELA, Fernanda; RAMALHO, Tatiany; PAIVA, Fernanda. Lei anticorrupção: Lei n. 12.846, de $1^{\circ}$ de Agosto de 2013. São Paulo: Saraiva, 2015.

MENDES, Franciso Schertel; DE CARVALHO, Vinícius Marques. Compliance: concorrência e combate à corrupção. São Paulo: Trevisan Editora, 2017.

MOHALLEM, Michael Freitas; RAGAZZO, Carlos Emmannue Joppert. Diagnóstico Institucional: primeiros passos para um plano nacional anticorrupção. Rio de Janeiro: Escola de Direito do Rio de Janeiro da Fundação Getúlio Vargas, 2017.

NIETO, Alejandro. Derecho Administrativo Sancionador. Madrid: Tecnos, 2006.

OSÓRIO, Fábio Medina. Direito administrativo sancionador. 2. ed. São Paulo: Ed. RT, 2006.

PAULA, Marco Aurélio Borges de. Efeitos da corrupção para o desenvolvimento. In: PAULA, Marco Aurélio Borges de; CASTRO, Rodrigo Pironti Aguirre de (Coord.). Compliance, gestão de riscos e combate à corrupção: integridade para o desenvolvimento. Belo Horizonte: Fórum, 2018.

PIMENTEL, Matheus. Por que o Brasil não pune a corrupção privada. Nexo Jornal, 14 nov. 2017. Disponívelem: [www.nexojornal.com.br/expresso/2017/11/14/ Por-que-o-Brasil-n\%C3\%A3o-pune-corrup\%C3\%A7\%C3\%A3o-privada]. Acesso em: 23.07.2018.

PROTIVITI. Nível de maturidade em compliance nas empresas brasileiras. 2017. Disponivelem: [www.protiviti.com/sites/default/files/infografico_-_nivel_de_maturidade_em_compliance_nas_empresas_brasileiras.pdf]. Acesso em: 20.07.2018.

REINO UNIDO. Bribery Act 2010. Disponível em: [www.legislation.gov.uk/ukpga/2010/23/pdfs/ukpga_20100023_en.pdf]. Acesso em: 24.07.2018.

RIBEIRO, Marcia Carla Pereira; DINIZ, Patrícia Dittrich Ferreira. Compliance e Lei Anticorrupção nas empresas. Revista de Informação Legislativa, Brasília, ano 52, n. 205, p. 98-103, jan.-mar. 2015.

SCHUESSLER, Karl F. Other People's Money: A Study in the Social Psychology of Embezzlement. Donald R. Cressey. American Journal of Sociology 59, Chicago, 6, p. 604, maio 1954. Disponível em: [https://doi.org/10.1086/221475]. Acesso em: 27.06.2018.

SERPA, Alexandre da Cunha. Guia descomplicado: um guia simples e direto sobre Programas de Compliance. 2016.

RODRIGUES, Matheus Vinicius Aguiar. No combate à corrupção empresarial, como incentivar normativamente a implementação efetiva do compliance? 
SILVEIRA, Renato de Mello Jorge; SAAD-DINIZ, Eduardo. Compliance, direito penal e lei anticorrupção. São Paulo: Saraiva, 2015.

SUÍÇA. Swiss Criminal Code. Disponível em: [www.admin.ch/opc/en/classified-compilation/19370083/201803010000/311.0.pdf]. Acesso em: 22.07.2018.

TAMASAUSKAS, Igor Sant'Anna; BOTTINI, Pierpaolo Cruz. A interpretação constitucional possível da responsabilidade objetiva na lei anticorrupção. Revista dos Tribunais, São Paulo, v. 103, n. 947, p. 133-155, set. 2014.

UNITED NATIONS GLOBAL COMPACT. A Practical Guide for Collective Action against Corruption. New York, 2015. Disponível em: [www.unglobalcompact. org/docs/issues_doc/Anti-Corruption/CollectiveActionExperiencesGlobal. pdf]. Acesso em: 23.07.2018.

WORLD ECONOMIC FORUM. The Global Competitiveness Report 2017-2018. Disponível em: [www3.weforum.org/docs/GCR2016-2017/05FullReport/TheGlobalCompetitivenessReport2016-2017_FINAL.pdf]. Acesso em: 02.06.2018.

ZENKNER, Marcelo. O papel do setor privado na promoção da integridade nos negócios. In: PAULA, Marco Aurélio Borges de; CASTRO, Rodrigo Pironti Aguirre de (Coord.). Compliance, gestão de riscos e combate à corrupção: integridade para o desenvolvimento. Belo Horizonte: Fórum, 2018.

\section{Pesouisas do Editorial}

\section{Veja também Doutrinas}

- A prática do compliance como um instrumento empresarial anticorrupção para preservação das empresas, de Fábia Duarte Ferreira - RDB 81/161-178 (DTR|2018|19496);

- Compliance: uma visão do compliance como forma de mitigação de responsabilidade, de Alexandre Baraldi Tonin - RT 983/265-288 (DTR|2017|5536); e

- Programas de integridade anticorrupção: autonomia e heteronomia, de Carlos Edinger RT 977/267-285 (DTR|2017/435).

RodrIGUES, Matheus Vinicius Aguiar. No combate à corrupção empresarial, como incentivar normativamente a implementação efetiva do compliance?

Revista de Direito Administrativo, Infraestrutura, Regulaçāo e Compliance n. 13. ano 4. p. 221-249. São Paulo: Ed. RT, abr.-jun. 2020. 